\title{
Application of Safety Attitudes Questionnaire (SAQ) in Adult Intensive Care Units: a cross-sectional study
}

\author{
Abdullah S. Alqahtani ${ }^{1,2}$, Rachel Evley ${ }^{2}$ \\ ${ }^{1}$ Department of Respiratory Care, Prince Sultan Military College of Health Sciences, Dammam, \\ Saudi Arabia
}

${ }^{2}$ Anaesthesia \& Critical Care, Division of Clinical Neuroscience, University of Nottingham, UK

Corresponding author: Abdullah S. Alqahtani, Anaesthesia \& Critical Care, Division of Clinical Neuroscience, University of Nottingham, UK, email: rt0075@hotmail.com

Source of Funding: None

Keywords: Saudi Arabia, Safety culture, Safety climate, Safety Attitudes Questionnaire 
medRxiv preprint doi: https://doi.org/10.1101/2020.07.07.20114918; this version posted July 7, 2020. The copyright holder for this preprint (which was not certified by peer review) is the author/funder, who has granted medRxiv a license to display the preprint in perpetuity. It is made available under a CC-BY-NC-ND 4.0 International license .

\section{Abstract:}

Purpose: To achieve a positive safety culture, staff perception of safety must be frequently measured. There are several active and reactive methods to use to measure safety cultures such as near-miss occurrence, accidental data collection, measuring behavior, self-report method, and safety questionnaires. The safety attitudes questionnaire (SAQ) tool was used to measure safety culture. This tool is widely used in literature and among researchers and has been used and validated in middle eastern cultures. In addition, it has a validated Arabic version.

Methods: A cross-sectional study was conducted using anonymous and random sampling. I surveyed all ICU staff working in all the adult ICUs in two of the major hospitals in the eastern province of Saudi Arabia. The short version of the Safety Attitudes Questionnaire was used to assess participants' attitudes towards safety culture. The study involved all healthcare providers working in Adult ICU.

Results: The study occurred over a three-week period in March 2019. A total of 82 completed questionnaires were returned which represented a response rate of $82 \%$. On average, the domain that scored the highest number of positive responses was Job satisfaction with $68.5 \%$, followed by teamwork climate $67.8 \%$, then working conditions $60.1 \%, 57.1 \%$ safety climate, then preparation of management with $53.4 \%$, and finally $46 \%$ in Stress recognition. A statistically significant difference was found between the mean SAQ score and the educational level of the participants. Participants with bachelor's degrees scored a mean of 50.17 compared to participants hold diploma degrees who scored a mean of $68.81(P=0.02)$. Moreover, a significant difference was found between the mean SAQ score and participants' specialties. Attending/Staff Physician mean score was 36.40, Nurse Manager/Charge Nurse scored 39.78, and Respiratory therapist mean score was 47.88 , compared to mean score of 62.27 for Registered Nurse, and Respiratory supervisor $67.0(P=0.04)$. In addition, $79.2 \%$ of the respondents did not report any incidents in the last 12 months.

Conclusions: The result of the study shows an unsatisfying level of safety culture among healthcare staff in ICUs. The importance of this study is to establish a baseline for safety climate in these hospitals and specifically ICUs. In addition, by exposing the system weaknesses it helps the administration to strengthen and improve patient care. By decreasing workload and job stress, studies show they have a positive association with increasing job performance. 
medRxiv preprint doi: https://doi.org/10.1101/2020.07.07.20114918; this version posted July 7, 2020. The copyright holder for this preprint (which was not certified by peer review) is the author/funder, who has granted medRxiv a license to display the preprint in perpetuity. It is made available under a CC-BY-NC-ND 4.0 International license .

\section{Introduction:}

Patient safety, prevention of medical error, and quality of care are important aspects of health care. The importance of these fields has led to an expansion in literature and research in recent years. As in any other profession or industry such as engineering, aviation, or nuclear plants, human factors play an important role in the generation of medical incidents (Reason 2000). The available literature seems to suggest that high a percentage of medical incidents could be prevented in many cases (Brennan et al. 1991).

To achieve a positive safety culture, first, was must understand the values, perceptions, and patterns of behaviors to determine what is the norms and what is appropriate.

After the Chernobyl disaster in 1986, more attention was given to safety culture in nuclear institutions. In 1993, the Advisory Committee on the Safety of Nuclear Installations (ACSNI) established a definition for safety culture as: "The safety culture of an organization is the product of individual and group values, attitudes, perceptions, competencies, and patterns of behavior that determine the commitment to, and the style and proficiency of, an organization's health and safety management.

Organizations with a positive safety culture are characterized by communications founded on mutual trust, by shared perceptions of the importance of safety and by confidence in the efficacy of preventive measures." (Health and Safety Commission (HSC) 1993).

Safety culture in a unit is a part of the whole organizational culture. Cooper described safety culture as a sub-facet of a bigger culture, the organizational culture (Cooper 2000). Moreover, cooper also suggests that safety culture affects organization members' attitudes and behavior about the organization's current health and safety performance (Cooper 2000). As well, the administration's perception of safety influences the staff safety culture (Gadd and Collins 2002). Communication-based on mutual trust and committing and understanding the importance and 
medRxiv preprint doi: https://doi.org/10.1101/2020.07.07.20114918; this version posted July 7, 2020. The copyright holder for this preprint (which was not certified by peer review) is the author/funder, who has granted medRxiv a license to display the preprint in perpetuity. It is made available under a CC-BY-NC-ND 4.0 International license .

benefits of following safety protocols are features of positive safety culture (Sorra and Nieva 2004).

In the Cooper framework, safety culture has three aspects: Psychological aspect, Behavioral aspect, and Situational aspect. The psychological aspect (This is also called the safety climate) which represents the individual's attitude, values, and perceptions. It can be measured by the safety climate questionnaire to capture a glimpse of staff attitude and perceptions toward safety at the point of time. However, in some studies, safety climate has come to be used to refer to safety culture alternatively (Gabrani et al. 2015; Soh et al. 2016). In some studies, safety climate has been described as the shared perceptions, attitudes, and beliefs of staff about the organization handle and archives safety (Flin et al. 2006; Soh et al. 2016). To reiterate Safety culture is how things are done around here, and safety climate is a glimpse or superficial image of safety culture in a specific time and place. However, throughout this paper, the term safety climate will be used to refer to the psychological aspect of safety culture.

The second aspect: the behavioral aspect, which focuses on individuals' actions can be examined by direct peer observations and self-reports.

Third aspect: the situational aspect, concerns the organization's policies, procedures, regulations, and organizational system. This aspect could be examined via inspections and surveillance (Cooper 2000; Health \& Safety Executive 2005).

As in different industries such as aviation and nuclear power, the Agency of Health Care Research and Quality (AHRQ) (Sorra et al. 2016), the Joint Commission for the Accreditation of Healthcare Organizations (Joint Commission 2018), and the National Health Service (NHS) (NHS England and NHS Improvement 2019) encourage the regulatory measurement of safety culture. To maintain or to improve safety culture it must be frequently measured. Measuring safety could be done actively or reactively. 
medRxiv preprint doi: https://doi.org/10.1101/2020.07.07.20114918; this version posted July 7, 2020. The copyright holder for this preprint (which was not certified by peer review) is the author/funder, who has granted medRxiv a license to display the preprint in perpetuity. It is made available under a CC-BY-NC-ND 4.0 International license .

Active measurement is done to monitor safety culture in the organization before an incident occurs; these measurements are done as inspections rather than investigation. On the other hand, reactive measurement is measuring safety culture after an incident took place, investigating the incident or near miss cases, and examining the safety culture at that moment (Gadd and Collins 2002).

There are several active and reactive methods to use to measure safety cultures such as nearmiss occurrence, accidental data collection, measuring behavior, self-report method, and safety questionnaires.

One of the common methods to actively assess safety culture is safety questionnaires and one of the most internationally used questionnaires is the Safety Attitude Questionnaire (SAQ) (Gabrani et al. 2015; Smits et al. 2017). SAQ was developed by the University of Texas and partially funded by $A H R C$, with the aim to fill the demand for healthcare quality regulations from the Joint Commission for the Accreditation of Healthcare Organizations, the Agency for Healthcare Research and Quality, and the U.S. National Quality to measure and monitor safety culture (Sexton et al. 2006).

SAQ has many strengths, it is popular among researchers and investigators, has a shorter questionnaire compared to others such as The Job Descriptive Index, tested and validated in different cultures worldwide, available in multi-language translations, ability to measure and monitor trend data over time, and ability to benchmark and utilize it within any unit in the hospital such as ICU and OR. (Etchegaray and Thomas 2012; Gabrani et al. 2015; Smits et al. 2017) SAQ ICU Arabic version is the most used validated tool in Arabic culture. SAQ was translated and validated (internal consistency) by Hamdan 2013 (Hamdan 2013). Moreover, Abu-El-Noor et al in the 2017 study confirmed Hamdan translation's, tested the psychometric properties (validity and reliability) and found good validation, they determined that it could be used as a tool to evaluate the safety attitudes in Arabic speaking hospital culture (Abu-El-Noor et al. 2017). 
medRxiv preprint doi: https://doi.org/10.1101/2020.07.07.20114918; this version posted July 7, 2020. The copyright holder for this preprint (which was not certified by peer review) is the author/funder, who has granted medRxiv a license to display the preprint in perpetuity. It is made available under a CC-BY-NC-ND 4.0 International license .

\section{Method:}

A cross-sectional study was conducted using anonymous and random sampling. I surveyed all ICU staff working in all the adult ICUs in two of the major hospitals in the eastern province of Saudi Arabia. The short version of the Safety Attitudes Questionnaire was used to assess participants' attitudes towards safety culture. Approval for the Questionnaire was gained from the University of Texas for the English version. Permission was obtained from Dr. Hamdan for the validated Arabic version of the Questionnaire.

It has 30 core items representing six scales: teamwork climate, safety climate, job satisfaction, stress recognition, perception of management, and working conditions. Additional items were added to explore the safety culture perception and the attitude toward incident reporting within the unit.

The following items were not part of the original Questionnaire: Item "How you score the intensive care unit in this hospital regarding patient safety", item "describe the quality of communication and collaboration with the following personnel during your experience in this ICU", and item "How many incidents (medical errors) did you report to the management in the last 12 months?".

The questionnaire uses a Likert-type scale, ranging from 5 for strongly agree, 4 slightly agree, 3 neutral, 2 slightly disagree, to 1 for strongly disagree. The overall domain score was calculated by summing all items in each domain then divided by the number of items.

\section{Data collection:}

Data collection for the study occurred over a three-week period in March 2019. The respondent criteria included all healthcare workers in the adult intensive care units with at least one year of experience and worked in the ICU for at least one month before the study. 
medRxiv preprint doi: https://doi.org/10.1101/2020.07.07.20114918; this version posted July 7, 2020. The copyright holder for this preprint (which was not certified by peer review) is the author/funder, who has granted medRxiv a license to display the preprint in perpetuity.

\section{Statistical Analysis:}

All data were transferred to an electronic worksheet in Microsoft® Excel on office 365. Then data were analyzed by using SPSS software (version 25 , Chicago, IL). A p-value of less than $5 \%$ was considered to be statistically significant. Cronbach's alpha was used to assess the reliability of each domain in the Questionnaire. Descriptive analysis was performed using ANOVA and paired sample t-tests in all demographic data including sex, age, educational level, job title, years of experience, working hours and working shifts and compared to SAQ mean scores.

\section{Results:}

A total of 82 completed questionnaires were returned which represented a response rate of $82 \%$. Table 1 shows the demographics of the questionnaire participants. $49 \%$ of the participants used the Arabic version of the Questionnaire versus $51 \%$ using the English version. $57 \%$ of the participants were male, and $43 \%$ were female. Among participants, around $45 \%$ were respiratory therapists, $45 \%$ were nurses, $9 \%$ were physicians, and one participant was an ICU nutrition specialist. Most of the participants were bachelor's degree holders (76\%), then diploma (18\%), and postgraduates (6\%). $63 \%$ of participants have a minimum of 5 years of experience. Regarding working hours, the majority were working 40 to 59 hours per week (83\%), and the part-time staff was $11.7 \%$. Around $72 \%$ of the participants' work schedule is variable and they cover night and day shifts, $22 \%$ work only day shifts, and $6 \%$ work night shifts. 
Table 1: Demographic data of respondents.

\begin{tabular}{|c|c|c|}
\hline Variables & Frequency & Percentage \\
\hline \multicolumn{3}{|l|}{$\operatorname{Sex}(n=79)$} \\
\hline Male & 45 & 57 \\
\hline Female & 34 & 43 \\
\hline \multicolumn{3}{|l|}{ Age $(n=75)$} \\
\hline$<=30$ Years & 40 & 53.3 \\
\hline$>30$ Years & 35 & 46.7 \\
\hline \multicolumn{3}{|l|}{ Educational Level ( $n=79$ ) } \\
\hline Diploma & 14 & 17.7 \\
\hline Bachelor's degree & 60 & 75.9 \\
\hline Master, Ph.D., or equivalent & 5 & 6.3 \\
\hline \multicolumn{3}{|l|}{ Job Title $(n=78)$} \\
\hline Staff Physician & 5 & 6.4 \\
\hline Nurse & 32 & 41.0 \\
\hline Resident Physician & 1 & 1.3 \\
\hline Respiratory Therapist & 33 & 42.3 \\
\hline ICU Head & 1 & 1.3 \\
\hline Nurse In-charge & 3 & 3.8 \\
\hline Respiratory Supervisor & 2 & 2.6 \\
\hline Nutrition Specialist & 1 & 1.3 \\
\hline \multicolumn{3}{|l|}{ Years in Profession $(n=79)$} \\
\hline$<=5$ Years & 29 & 36.7 \\
\hline$>5$ Years & 50 & 63.3 \\
\hline \multicolumn{3}{|l|}{ Years in ICU $(n=79)$} \\
\hline$<=5$ Years & 43 & 54.4 \\
\hline$>5$ Years & 36 & 45.6 \\
\hline \multicolumn{3}{|l|}{ Work hours per week $(n=77)$} \\
\hline Less than 39 (part-time) & 9 & 11.7 \\
\hline 40 to 59 hours & 64 & 83.1 \\
\hline 60 to 79 hours & 2 & 2.6 \\
\hline 80 hours and more & 2 & 2.6 \\
\hline \multicolumn{3}{|l|}{ Work shift $(n=79)$} \\
\hline Day & 17 & 21.5 \\
\hline Night & 5 & 6.3 \\
\hline Variable shifts & 57 & 72.2 \\
\hline \multicolumn{3}{|c|}{ Number of incidents reported to the } \\
\hline \multicolumn{3}{|l|}{ Management $(n=80)$} \\
\hline None & 62 & 77.5 \\
\hline $1-2$ incidents & 18 & 22.5 \\
\hline \multicolumn{3}{|l|}{ Language of survey $(n=82)$} \\
\hline Arabic & 40 & 48.8 \\
\hline English & 42 & 51.2 \\
\hline
\end{tabular}


medRxiv preprint doi: https://doi.org/10.1101/2020.07.07.20114918; this version posted July 7, 2020. The copyright holder for this preprint (which was not certified by peer review) is the author/funder, who has granted medRxiv a license to display the preprint in perpetuity. It is made available under a CC-BY-NC-ND 4.0 International license .

The participant's mean scores for each item of the six domains and the percentage of positive responses are presented in Table 2. On average, the domain that scored the highest number of positive responses was Job satisfaction with $68.5 \%$, followed by teamwork climate $67.8 \%$, then working conditions $60.1 \%, 57.1 \%$ safety climate, then preparation of management with $53.4 \%$, and finally $46 \%$ in Stress recognition. Figure 1 demonstrates the average percentage of positive responses per SAQ domain.

The Pearson correlation analysis was used to determine the associations between participants' positive response and each SAQ domain, the reliability analysis was done using Cronbach $\alpha$ method and showed that the Cronbach a values.

Overall, the SAQ had very good internal consistency (Cronbach's $\alpha=0.91$ ). The domains internal consistency showed good results for Job satisfaction (Cronbach's $\alpha=0.86$ ), Safety Climate (Cronbach's $\alpha=0.77$ ), Working conditions (Cronbach's $\alpha=0.84$ ), and Stress recognition (Cronbach's $\alpha=0.71$ ). And acceptable internal consistency in Preparation of Management (Cronbach's $\alpha=0.70$ ), and Teamwork climate (Cronbach's $\alpha=0.68$ ) which fall within the acceptable range (De Vet et al. 2011).

Table 3 shows the mean SAQ score of participants according to their characteristics. A statistically significant difference was found between the mean SAQ score and the educational level of the participants. Participants with bachelor's degrees scored a mean of 50.17 compared to participants hold diploma degrees who scored a mean of $68.81(P=0.02)$. Moreover, a significant difference was found between the mean SAQ score and participants' specialties. Attending/Staff Physician mean score was 36.40, Nurse Manager/Charge Nurse scored 39.78, and Respiratory therapist mean score was 47.88, compared to mean score of 62.27 for Registered Nurse, and Respiratory supervisor $67.0(P=0.04)$. 
medRxiv preprint doi: https://doi.org/10.1101/2020.07.07.20114918; this version posted July 7, 2020. The copyright holder for this preprint (which was not certified by peer review) is the author/funder, who has granted medRxiv a license to display the preprint in perpetuity. It is made available under a CC-BY-NC-ND 4.0 International license .

Table 4 shows the mean SAQ score of both hospitals in each domain. Perception of management scored a mean of 28.65 in hospital 2 compared to 62.22 in hospital 1. Hospital 2 working condition scored a mean of 29.05 , compared to 74.33 in hospital 1 . Moreover, the safety climate mean score in hospital 2 was 37.22, and hospital 1 was 69.97 . This could be explained by the significant difference in management and working conditions in both hospitals. Hospital 1 is a military hospital that is managed by the Ministry of Defense and serves only the Ministry of Defense workers and their families. Whereas Hospital 2 is under the Ministry of Health administration and serves the public residents of the region and is therefore expected to have a higher workload compared to hospital 1. In addition, even though the bed capacity of hospital 2 (425 beds) is more than hospital 1 (335 beds) the staffing in hospital 2 is insufficient and therefore working conditions and perception of management mean score was immensely negative.

One of the added items to the Questionnaire was the number of incidents reported by the participants in the last 12 months. Based on the responses, table 5 shows $79.2 \%$ of the respondents did not report any incidents in the last 12 months. $20.7 \%$ report one or two incidents in the last 12 months and no participant have reported more than two incidents (figure 2).

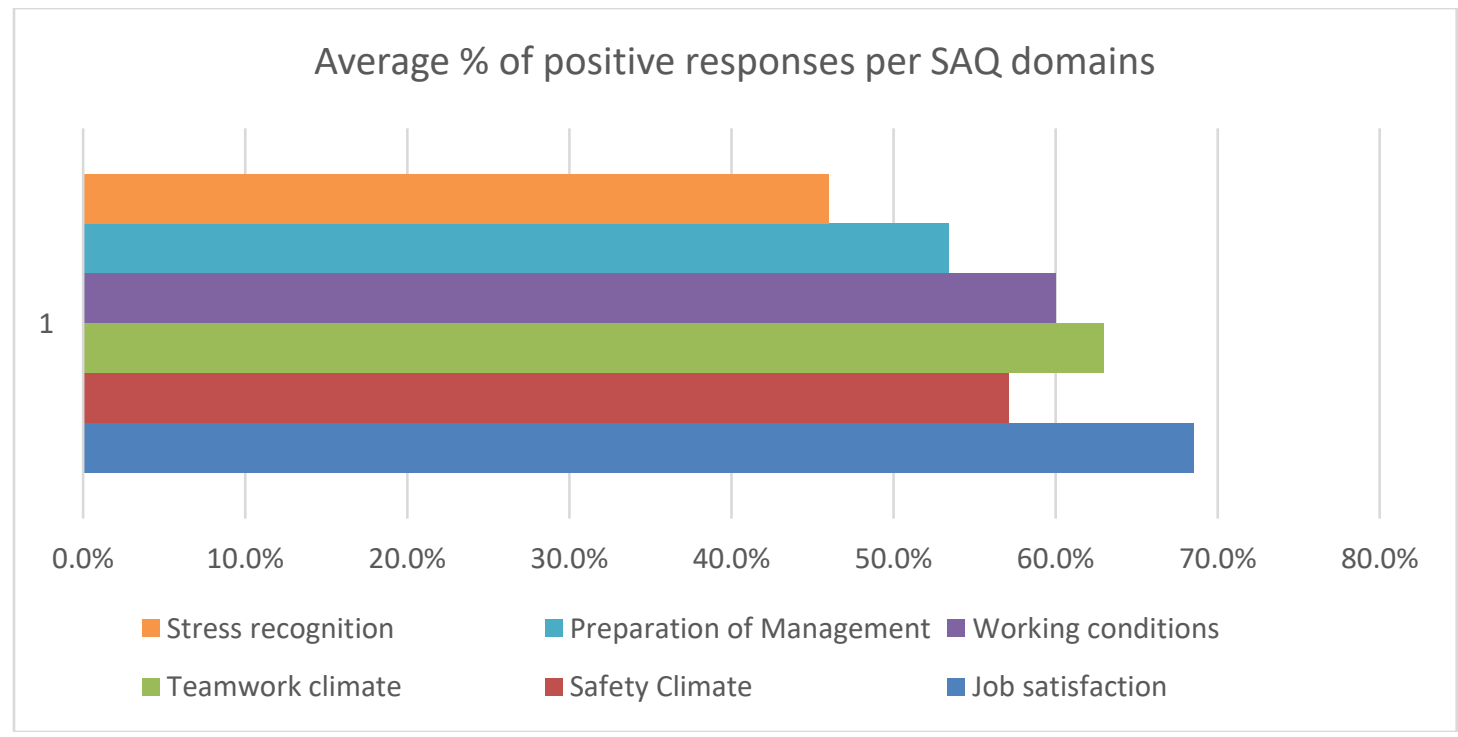

Figure 1: Average of percentage positive responses per SAQ domains. 
medRxiv preprint doi: https://doi.org/10.1101/2020.07.07.20114918; this version posted July 7, 2020. The copyright holder for this preprint (which was not certified by peer review) is the author/funder, who has granted medRxiv a license to display the preprint in perpetuity. It is made available under a CC-BY-NC-ND 4.0 International license .

Table 2: SAQ Domains and items, scales' mean scores, and percentages of positive responses.

\begin{tabular}{|c|c|c|c|}
\hline & Mean & SD & $\begin{array}{l}\% \text { of Positive } \\
\text { Responses }\end{array}$ \\
\hline \multicolumn{4}{|l|}{ Job satisfaction (Cronbach's $\alpha=0.86$ ) } \\
\hline I like my Job & 3.56 & 2.07 & 75.7 \\
\hline Working here is like being part of a large family & 3.07 & 2.20 & 67.0 \\
\hline This is a good place to work. & 3.04 & 2.24 & 65.8 \\
\hline I am proud to work in this clinical area. & 3.38 & 2.10 & 73.1 \\
\hline Morale in this clinical area is high. & 2.72 & 2.22 & 60.9 \\
\hline \multicolumn{4}{|l|}{ Safety Climate (Cronbach's $\alpha=0.77$ ) } \\
\hline I would feel safe being treated here as a patient & 2.40 & 2.33 & 52.5 \\
\hline Medical errors are handled appropriately in this clinical area & 2.38 & 2.36 & 51.2 \\
\hline $\begin{array}{l}\text { I know the proper channels to direct questions regarding patient safety in this } \\
\text { clinical area. }\end{array}$ & 3.02 & 2.17 & 67.0 \\
\hline I receive appropriate feedback about my performance. & 2.99 & 2.09 & 68.3 \\
\hline In this clinical area, it is difficult to discuss errors. & 1.48 & 2.02 & 35.4 \\
\hline $\begin{array}{l}\text { I am encouraged by my colleagues to report any patient safety concerns I may } \\
\text { have. }\end{array}$ & 2.83 & 2.14 & 64.6 \\
\hline \multicolumn{4}{|l|}{ Teamwork climate (Cronbach's $\alpha=0.68$ ) } \\
\hline Nurse input is well received in this clinical area & 3.37 & 2.09 & 73.2 \\
\hline $\begin{array}{l}\text { In this clinical area, it is difficult to speak up if I perceive a problem with patient } \\
\text { care }\end{array}$ & 1.00 & 1.85 & 23.2 \\
\hline $\begin{array}{l}\text { Disagreements in this clinical area are resolved appropriately (i.e., not who is } \\
\text { right, but what is best for the patient). }\end{array}$ & 2.65 & 2.27 & 58.5 \\
\hline I have the support I need from other personnel to care for patients & 3.43 & 2.07 & 74.4 \\
\hline $\begin{array}{l}\text { It is easy for personnel here to ask questions when there is something that } \\
\text { they do not understand. }\end{array}$ & 3.45 & 2.02 & 75.6 \\
\hline \multicolumn{4}{|l|}{ Working conditions (Cronbach's $\alpha=0.84$ ) } \\
\hline Problem personnel are dealt with constructively by our department. & 2.09 & 2.23 & 47.6 \\
\hline This hospital does a good job of training new personnel. & 2.82 & 2.25 & 62.2 \\
\hline $\begin{array}{l}\text { All the necessary information for diagnostic and therapeutic decisions is } \\
\text { routinely available to me. }\end{array}$ & 2.93 & 2.16 & 65.9 \\
\hline Trainees in my discipline are adequately supervised. & 2.95 & 2.23 & 64.6 \\
\hline \multicolumn{4}{|l|}{ Preparation of Management (Cronbach's $\alpha=0.70$ ) } \\
\hline Management supports my daily efforts: & 2.24 & 2.18 & 52.4 \\
\hline Management doesn't knowingly compromise patient safety. & 2.76 & 2.31 & 59.8 \\
\hline I get adequate, timely info about events that might affect my work. & 2.44 & 2.20 & 56.1 \\
\hline $\begin{array}{l}\text { The levels of staffing in this clinical area are sufficient to handle the number of } \\
\text { patients }\end{array}$ & 1.98 & 2.22 & 45.1 \\
\hline \multicolumn{4}{|l|}{ Stress recognition (Cronbach's $\alpha=0.71$ ) } \\
\hline When my workload becomes excessive, my performance is impaired. & 2.05 & 2.24 & 46.3 \\
\hline I am less effective at work when fatigued. & 2.54 & 2.18 & 58.5 \\
\hline I am more likely to make errors in tense or hostile situations. & 1.71 & 2.23 & 37.8 \\
\hline $\begin{array}{l}\text { Fatigue impairs my performance during emergency situations (e.g. emergency } \\
\text { resuscitation, seizure). }\end{array}$ & 1.85 & 2.24 & 41.5 \\
\hline Overall SAQ (Cronbach's $\alpha=0.91)$ & 2.64 & 1.13 & \\
\hline
\end{tabular}


medRxiv preprint doi: https://doi.org/10.1101/2020.07.07.20114918; this version posted July 7, 2020. The copyright holder for this preprint (which was not certified by peer review) is the author/funder, who has granted medRxiv a license to display the preprint in perpetuity.

It is made available under a CC-BY-NC-ND 4.0 International license .

Incidents reported by the participants in the last 12 months

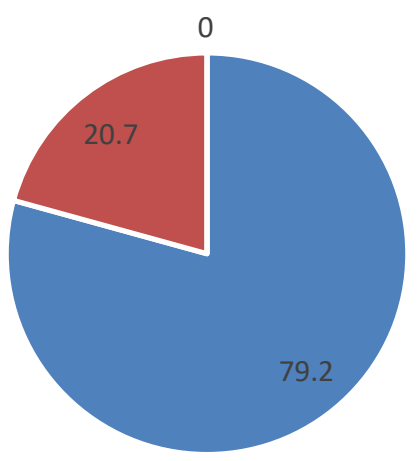

- Participant's who didn't report any incidents

- Participant's who report 1-2 incidents

- Participant's who reported more than 2 incidents = zero

Figure 2: Number of incidents reported by participants in the last 12 months.

Table 3:Association between participant characteristics and overall SAQ scores.

\begin{tabular}{|c|c|c|c|}
\hline & Mean & SD & P-value \\
\hline $\operatorname{Sex}(n=79)$ & & & 0.43 \\
\hline Male & 55.08 & 23.23 & \\
\hline Female & 52.10 & 20.70 & \\
\hline Age $(n=75)$ & & & 0.30 \\
\hline$<=30$ Years & 51.22 & 20.94 & \\
\hline$>30$ Years & 56.42 & 23.49 & \\
\hline Educational Level $(n=79)$ & & & 0.02 \\
\hline Diploma & 68.81 & 17.26 & \\
\hline bachelor's degree & 50.17 & 22.17 & \\
\hline Master, Ph.D., or equivalent & 55.33 & 17.48 & \\
\hline Job Title $(n=78)$ & & & 0.04 \\
\hline Attending/Staff Physician & 36.40 & 8.39 & \\
\hline Registered Nurse & 62.27 & 22.30 & \\
\hline Respiratory therapist & 47.88 & 21.09 & \\
\hline Fellow Physician & 70.00 & nil & \\
\hline Nurse Manager/Charge Nurse & 39.78 & 13.68 & \\
\hline Unit Head & 67.33 & nil & \\
\hline Respiratory supervisor & 67 & 0.47 & \\
\hline Nutrition & 78.67 & nil & \\
\hline Years in Profession $(n=79)$ & & & 0.65 \\
\hline$<=5$ Years & 55.29 & 21.62 & \\
\hline$>5$ Years & 52.93 & 22.52 & \\
\hline
\end{tabular}




\begin{tabular}{llll}
\hline Years in ICU $(\mathrm{n}=79)$ & \multicolumn{3}{c}{0.24} \\
$<=5$ Years & 56.50 & 23.10 & \\
$>5$ Years & 50.57 & 20.66 & \\
\hline Work hours per week $(\mathrm{n}=77)$ & & \multicolumn{3}{c}{0.94} \\
Less than 39(part-time) & 53.85 & 26.24 & \\
40 to 59 hours & 53.42 & 21.98 & \\
60 to 79 hours & 43.33 & 5.66 & \\
80 hours and more & 52.00 & 25.46 & \\
\hline Work shift $(\mathrm{n}=79)$ & & & 0.28 \\
Day & 55.61 & 20.42 & \\
Night & 38.53 & 18.05 & \\
Variable shifts & 54.60 & 22.68 & \\
\hline Number of incidents reported to the & & & 0.21 \\
Management $(n=80)$ & & & \\
None & 52.12 & & \\
1 - 2 incidents & 59.48 & & \\
\hline
\end{tabular}

Table 4: Comparison between the result of both hospitals.

\begin{tabular}{lcccc}
\hline Domain & \multicolumn{2}{c}{ Hospital 1 } & \multicolumn{2}{c}{ Hospital 2 } \\
\cline { 2 - 5 } & Mean & SD & Mean & SD \\
\hline Job Satisfaction & 76.71 & 30.17 & 46.49 & 32.41 \\
Safety Climate & 61.97 & 25.21 & 37.22 & 25.93 \\
Teamwork Climate & 66.67 & 21.09 & 46.58 & 26.88 \\
Working Conditions & 74.33 & 27.11 & 29.05 & 30.66 \\
Perception of management & 62.22 & 25.73 & 28.65 & 29.12 \\
Stress recognition & 35.44 & 28.16 & 47.16 & 36.22 \\
\hline
\end{tabular}

Table 5:Number of incidents reported by participants per specialty in the last 12 months.

\begin{tabular}{ccccccccccc}
\hline $\begin{array}{c}\text { \# of incidents } \\
\text { reported }\end{array}$ & \multicolumn{2}{c}{ All participants } & \multicolumn{2}{c}{ Physicians } & \multicolumn{2}{c}{ Nurses } & \multicolumn{2}{c}{ RT } & \multicolumn{2}{c}{ Others } \\
\hline & F & $\%$ & F & $\%$ & F & $\%$ & F & $\%$ & F & $\%$ \\
\hline $\mathbf{1 - 2}$ & 17 & 20.7 & 3 & 3.7 & 7 & 8.5 & 6 & 7.3 & 1 & 1.2 \\
None & 65 & 79.2 & 3 & 3.7 & 28 & 34.1 & 29 & 35.4 & 5 & 6.1 \\
\hline
\end{tabular}

\section{Discussion:}

Healthcare accreditation organizations such as Joint Commission International (JCI), United Kingdom Accreditation Service (UKAS) and the Saudi Central Board for Accreditation of Healthcare Institutions (CBAHI), encourage hospitals to frequently assess safety culture within 
medRxiv preprint doi: https://doi.org/10.1101/2020.07.07.20114918; this version posted July 7, 2020. The copyright holder for this preprint (which was not certified by peer review) is the author/funder, who has granted medRxiv a license to display the preprint in perpetuity. It is made available under a CC-BY-NC-ND 4.0 International license .

the institution. In Saudi Arabia, the safety culture research field is still relatively new and underexplored and has very limited published data in measuring safety culture and the use of SAQ (Alayed, Lööf, and Johansson 2014; Algahtani 2015; Alswat et al. 2017; Alzahrani, Jones, and Abdel-Latif 2018). The findings of this study show similarity to results from other studies (Abu-ElNoor et al. 2017; Gabrani et al. 2015; Hamdan 2013; Sexton et al. 2006; Vifladt et al. 2016; Zhao et al. 2019).

In this study, results show a significant difference between nurses and other specialties. Nurses scored a higher positive attitude toward safety culture. The result is in line with the findings from the Abu-El-Noo study (Abu-El-Noor et al. 2017). This difference could be related to the fact that most of the nurses were younger and felt more informed toward safety culture, they may also be more resilient and able to cope with stressful working conditions in ICU (Raftopoulos and Pavlakis 2013a). However, other studies reported that physicians scored higher than nurses (Gabrani et al. 2015; Sexton et al. 2006; Thomas, Sexton, and Helmreich 2003). The difference in SAQ scores between healthcare specialties could be related to safety culture inside their department, responsibilities, availability of protocols, training, and gender (Thomas et al. 2003).

Another significant difference was found between staff holding diploma degree who scored higher compared to higher educated staff. This could be related to the fact that most of the diploma staff were working in their ICUs for a longer time than others and they were more familiar with the unit policies and team. Findings in this study indicate that staff working in night shifts scored lower overall SAQ than the day shift. Various studies found that safety and productivity are compromised during night shifts (Folkard and Tucker 2003; Gomez-Garcia et al. 2016; Wagstaff and Lie 2011).

In this study, job satisfaction was scored the highest positive domain among all domains despite the fact that the stress recognition domain scored the lowest $46 \%$ and more than $55 \%$ of 
medRxiv preprint doi: https://doi.org/10.1101/2020.07.07.20114918; this version posted July 7, 2020. The copyright holder for this preprint (which was not certified by peer review) is the author/funder, who has granted medRxiv a license to display the preprint in perpetuity. It is made available under a CC-BY-NC-ND 4.0 International license .

participants believe the ICU staffing is insufficient. However, these results were consistent with findings from other studies (Hamdan 2013; Raftopoulos and Pavlakis 2013b). This could be explained by firstly, the high working morale since $75.7 \%$ of participants answered positively to the item "I like my Job" which was the highest scored item in SAQ. Secondly, by the positive teamwork domain, which scored $67.8 \%$ positive response ( $2^{\text {nd }}$ highest domain) which could be a result of ICU staff familiarity with each other. Moreover, it was noticed that some of the young staff were trained during their internship in these units; therefore, they feel loyal to the team.

The stress recognition domain scored the lowest in both hospitals. This finding is consistent with other studies (Raftopoulos and Pavlakis 2013b). This could be a result of working in a stressful, fast-paced environment, and staff been burned out. In addition, Item "Problem personnel are dealt with constructively by our department" in the working condition received only $47.6 \%$ positive response. Several studies showed a correlation between high workload, stressful working conditions, and the number of incidents rate (Abu-El-Noor et al. 2017; Ahola et al. 2009; Fahrenkopf et al. 2008; Guirardello 2017).

The results of overall SAQ show a significant deferent between both ICUs. However, the variation in overall SAQ score between hospitals is common and expected as a result of different management, financial status, staff level, and type of patients (Hamdan 2013; Raftopoulos and Pavlakis 2013b).

Hospital 1 had recently initiated a safety educational program among the hospital staff, which could explain the relatively positive attitude of their staff toward safety culture. However, both hospitals showed a lack of proper reporting system and staff unwilling to report incidents (Table 5). This could be a result of many reasons such as lack of staff awareness about the importance of reporting incidents, or fear of punishment and liability. In the survey $35.4 \%$ of participants had felt that: "In this clinical area, it is difficult to discuss errors" and $23.2 \%$ of participants felt that: "In 
medRxiv preprint doi: https://doi.org/10.1101/2020.07.07.20114918; this version posted July 7, 2020. The copyright holder for this preprint (which was not certified by peer review) is the author/funder, who has granted medRxiv a license to display the preprint in perpetuity. It is made available under a CC-BY-NC-ND 4.0 International license .

this clinical area, it is difficult to speak up if I perceive a problem with patient care", moreover only $51.2 \%$ of participants believes that "Medical errors are handled appropriately in this clinical area". which indicates that the existing culture in the ICUs is not supportive and reliable toward reporting incidents and patient safety culture. Only $52.5 \%$ of staff said they felt safe to be treated in their hospitals, which is a strong indicator of poor patient safety.

Several studies showed that safety culture has a strong association with patient safety and incidents rate (Lee et al. 2010, 2019; Nieva and Sorra 2003; Pettker et al. 2011; Sexton et al. 2006; Tear et al. 2020). Moreover, more studies suggest that inability or difficulty for staff to report or to discuss incidents is one of the main reasons for poor patient safety culture (BuljacSamardzic, Van Wijngaarden, and Dekker-Van Doorn 2016; Sexton et al. 2006). Therefore, further investigation is needed from both hospital administration to highlight the staff concerns and work in improving the safety culture.

\section{Conclusion:}

The result of the study shows an unsatisfying level of safety culture among healthcare staff in these 2 ICUs. The importance of this study is to establish a baseline for safety climate in these hospitals and specifically ICUs. In addition, by exposing the system weaknesses it helps the administration to strengthen and improve patient care. By Decreasing workload and job stress, studies show they have a positive association with increasing job performance (Raziq and Maulabakhsh 2015). The use of questionnaires should be done periodically to assess safety culture over a period of time and observe the direction of the results.

\section{Limitations:}

Using a questionnaire to evaluate safety culture or to be specific safety climate, plays an important role in drawing the road map of the institution safety culture assessment. However, SAQ is not 
medRxiv preprint doi: https://doi.org/10.1101/2020.07.07.20114918; this version posted July 7, 2020. The copyright holder for this preprint (which was not certified by peer review) is the author/funder, who has granted medRxiv a license to display the preprint in perpetuity. It is made available under a CC-BY-NC-ND 4.0 International license.

enough, other tools should be used to inspect other aspects of safety culture. SAQ measures staff beliefs about safety culture rather than their actual safety behavior (Gadd and Collins 2002). Furthermore, the sample size was limited; therefore, the findings should be dealt with caution in regard to transferability. In addition, the participation of specialties such as physicians, clinical pharmacists, and others was poor and needed to be further investigated. 
medRxiv preprint doi: https://doi.org/10.1101/2020.07.07.20114918; this version posted July 7, 2020. The copyright holder for this preprint (which was not certified by peer review) is the author/funder, who has granted medRxiv a license to display the preprint in perpetuity. It is made available under a CC-BY-NC-ND 4.0 International license .

\section{References:}

Abu-El-Noor, Nasser Ibrahim, Motasem Abduallah Hamdan, Mysoon Khalil Abu-El-Noor, Abdal Karim Said Radwan, and Ahmed Ali Alshaer. 2017. "Safety Culture in Neonatal Intensive Care Units in the Gaza Strip, Palestine: A Need for Policy Change." Journal of Pediatric Nursing 33:76-82.

Ahola, K., S. Toppinen-Tanner, P. Huuhtanen, A. Koskinen, and A. Väänänen. 2009.

"Occupational Burnout and Chronic Work Disability: An Eight-Year Cohort Study on Pensioning among Finnish Forest Industry Workers." Journal of Affective Disorders 115(12):150-59.

Alayed, Abdulrahman S., Helena Lööf, and Unn-Britt Johansson. 2014. "Saudi Arabian ICU Safety Culture and Nurses' Attitudes." International Journal of Health Care Quality Assurance 27(7):581-93.

Algahtani, Fahad Dhafer. 2015. "The Culture in Safety Culture: Exploration of Patient Safety Culture in Saudi Arabian Operating Theatres."

Alswat, Khalid, Rawia Ahmad, Mustafa Abdalla, Maher Abdelraheim Titi, Maram Bakash, Faiza Mehmood, Beena Zubairi, Diana Jamal, and Fadi El-Jardali. 2017. "Improving Patient Safety Culture in Saudi Arabia (2012-2015): Trending, Improvement and Benchmarking." BMC Health Services Research 17(516).

Alzahrani, Naif, Russell Jones, and Mohamed E. Abdel-Latif. 2018. "Attitudes of Doctors and Nurses toward Patient Safety within Emergency Departments of Two Saudi Arabian Hospitals." BMC Health Services Research 18(736).

Brennan, Troyen a, Lucian L. Leape, N. a N. M. Laird, D. Ph, Liesi Hebert, D. Sc, a Russell Localio, a N. N. G. Lawthers, Joseph P. Newhouse, Paul C. Weiler, M. LI, and Howard H. Hiatt. 1991. "SPECIAL ARTICLES INCIDENCE OF ADVERSE EVENTS AND NEGLIGENCE IN HOSPITALIZED PATIENTS Results of the Harvard Medical Practice Study I." N Engl J Med 324(6):370-76.

Buljac-Samardzic, Martina, Jeroen D. H. Van Wijngaarden, and Connie M. Dekker-Van Doorn. 2016. "Safety Culture in Long-Term Care: A Cross-Sectional Analysis of the Safety Attitudes Questionnaire in Nursing and Residential Homes in the Netherlands." BMJ Quality and Safety 25(6).

Cooper, M. D. 2000. "Towards a Model of Safety Culture." Safety Science 36:111-36.

Etchegaray, Jason M. and Eric J. Thomas. 2012. "Comparing Two Safety Culture Surveys: Safety Attitudes Questionnaire and Hospital Survey on Patient Safety." BMJ Qual Saf 21:490-98.

Fahrenkopf, Amy M., Theodore C. Sectish, Laura K. Barger, Paul J. Sharek, Daniel Lewin, Vincent W. Chiang, Sarah Edwards, Bernhard L. Wiedermann, and Christopher P. 
medRxiv preprint doi: https://doi.org/10.1101/2020.07.07.20114918; this version posted July 7, 2020. The copyright holder for this preprint (which was not certified by peer review) is the author/funder, who has granted medRxiv a license to display the preprint in perpetuity. It is made available under a CC-BY-NC-ND 4.0 International license .

Landrigan. 2008. "Rates of Medication Errors among Depressed and Burnt out Residents: Prospective Cohort Study." Bmj 336(7642):488-91.

Flin, R., C. Burns, K. Mearns, and S. Yule. 2006. "Measuring Safety Climate in Health Care." Qual Saf Health Care 15:109-15.

Folkard, Simon and Philip Tucker. 2003. "Shift Work, Safety and Productivity." Occupational Medicine 53(2):95-101.

Gabrani, Adriatik, Adrian Hoxha, Artan Simaku, and Jonila Cyco. 2015. "Application of the Safety Attitudes Questionnaire (SAQ) in Albanian Hospitals: A Cross-Sectional Study." BMJ Open 5(e006528).

Gadd, S. and A. M. Collins. 2002. Safety Culture: A Review of the Literature. sheffield.

Gomez-Garcia, Teresa, Maria Ruzafa-Martinez, Carmen Fuentelsaz-Gallego, Juan Antonio Madrid, Maria Angeles Rol, Maria Jose Martinez-Madrid, and Teresa Moreno-Casbas. 2016. "Nurses' Sleep Quality, Work Environment and Quality of Care in the Spanish National Health System: Observational Study among Different Shifts." BMJ Open 6(8).

Guirardello, Edinêis de Brito. 2017. "Impact of Critical Care Environment on Burnout, Perceived Quality of Care and Safety Attitude of the Nursing Team." Revista Latino-Americana de Enfermagem 25.

Hamdan, Motasem. 2013. "Measuring Safety Culture in Palestinian Neonatal Intensive Care Units Using the Safety Attitudes Questionnaire." Journal of Critical Care 28(5):886.e7886.e14.

Health \& Safety Executive. 2005. A Review of Safety Culture and Safety Climate Literature for the Development of the Safety Culture Inspection Toolkit.

Health and Safety Commission (HSC). 1993. ACSNI Study Group on Human Factors. London: H.M.S.O.

Joint Commission. 2018. "Patient Safety Systems ( PS )." Comprehensive Accreditation Manual for Hospitals 1(January):1-48.

Lee, Seung Eun, Linda D. Scott, V. Susan Dahinten, Catherine Vincent, Karen Dunn Lopez, and Chang Gi Park. 2019. "Safety Culture, Patient Safety, and Quality of Care Outcomes: A Literature Review.” Western Journal of Nursing Research 41(2).

Lee, Wui Chiang, Hwei Ying Wung, Hsun Hsiang Liao, Chien Ming Lo, Fei Ling Chang, Pa Chun Wang, Angela Fan, Hsin Hsin Chen, Han Chuan Yang, and Sheng Mou Hou. 2010. "Hospital Safety Culture in Taiwan: A Nationwide Survey Using Chinese Version Safety Attitude Questionnaire." BMC Health Services Research 10.

NHS England and NHS Improvement. 2019. The NHS Patient Safety Strategy. Safer Culture, Safer Systems, Safer Patients. 
medRxiv preprint doi: https://doi.org/10.1101/2020.07.07.20114918; this version posted July 7, 2020. The copyright holder for this preprint (which was not certified by peer review) is the author/funder, who has granted medRxiv a license to display the preprint in perpetuity. It is made available under a CC-BY-NC-ND 4.0 International license .

Nieva, V. F. and J. Sorra. 2003. "Safety Culture Assessment: A Tool for Improving Patient Safety in Healthcare Organizations." BMJ Quality \& Safety 12(2):17-23.

Pettker, Christian M., Stephen F. Thung, Cheryl A. Raab, Katie P. Donohue, Joshua A. Copel, Charles J. Lockwood, and Edmund F. Funai. 2011. "A Comprehensive Obstetrics Patient Safety Program Improves Safety Climate and Culture." in American Journal of Obstetrics and Gynecology. Vol. 204.

Raftopoulos, Vasilios and Andreas Pavlakis. 2013a. "Safety Climate in 5 Intensive Care Units: A Nationwide Hospital Survey Using the Greek-Cypriot Version of the Safety Attitudes Questionnaire." Journal of Critical Care.

Raftopoulos, Vasilios and Andreas Pavlakis. 2013b. "Safety Climate in 5 Intensive Care Units: A Nationwide Hospital Survey Using the Greek-Cypriot Version of the Safety Attitudes Questionnaire." Journal of Critical Care 28(1):51-61.

Raziq, Abdul and Raheela Maulabakhsh. 2015. "Impact of Working Environment on Job Satisfaction.” Procedia Economics and Finance 23:717-25.

Reason, James. 2000. Education and Debate Human Error: Models and Management. Vol. 320.

Sexton, John B., Robert L. Helmreich, Torsten B. Neilands, Kathy Rowan, Keryn Vella, James Boyden, Peter R. Roberts, and Eric J. Thomas. 2006. "The Safety Attitudes Questionnaire: Psychometric Properties, Benchmarking Data, and Emerging Research.” BMC Health Services Research 6(44).

Smits, Marleen, Ellen Keizer, Paul Giesen, Ellen Catharina, Tveter Deilkås, Dag Hofoss, and Gunnar Tschudi Bondevik. 2017. "The Psychometric Properties of the 'safety Attitudes Questionnaire' in out-of-Hours Primary Care Services in the Netherlands." PLOS ONE 12(2):e0172390.

Soh, Sze Ee, Anna Barker, Renata Morello, Megan Dalton, and Caroline Brand. 2016. "Measuring Safety Climate in Acute Hospitals: Rasch Analysis of the Safety Attitudes Questionnaire." BMC Health Services Research 16(1).

Sorra, Joann, Laura Gray, Suzanne Streagle, Theresa Famolaro, Naomi Yount, and Jessica Behm. 2016. AHRQ Hospital Survey on Patient Safety Culture : User's Guide. Vol. January.

Sorra, Joann and Veronica Nieva. 2004. Hospital Survey on Patient Safety Culture (Prepared by Westat, under Contract No. 290-96-0004).

Tear, Morgan J., Tom W. Reader, Steven Shorrock, and Barry Kirwan. 2020. "Safety Culture and Power: Interactions between Perceptions of Safety Culture, Organisational Hierarchy, and National Culture." Safety Science 121.

Thomas, Eric J., J. Bryan Sexton, and Robert L. Helmreich. 2003. "Discrepant Attitudes about Teamwork among Critical Care Nurses and Physicians." Critical Care Medicine 31(3). 
medRxiv preprint doi: https://doi.org/10.1101/2020.07.07.20114918; this version posted July 7, 2020. The copyright holder for this preprint (which was not certified by peer review) is the author/funder, who has granted medRxiv a license to display the preprint in perpetuity. It is made available under a CC-BY-NC-ND 4.0 International license.

De Vet, Henrica C. W., Caroline B. Terwee, Lidwine B. Mokkink, and Dirk L. Knol. 2011. Measurement in Medicine: A Practical Guide. Cambridge University Press.

Vifladt, Anne, Bjoerg O. Simonsen, Stian Lydersen, and Per G. Farup. 2016. "Changes in Patient Safety Culture after Restructuring of Intensive Care Units: Two Cross-Sectional Studies." Intensive and Critical Care Nursing 32:58-65.

Wagstaff, Anthony Sverre and Jenny Anne Sigstad Lie. 2011. "Shift and Night Work and Long Working Hours - a Systematic Review of Safety Implications." Scandinavian Journal of Work, Environment and Health 37(3):173-85.

Zhao, Chuang, Qing Chang, Xi Zhang, Qijun Wu, Nan Wu, Jiao He, and Yuhong Zhao. 2019. "Evaluation of Safety Attitudes of Hospitals and the Effects of Demographic Factors on Safety Attitudes: A Psychometric Validation of the Safety Attitudes and Safety Climate Questionnaire." BMC Health Services Research 19(836). 